\title{
Pelatihan Kewirausahaan Pada Masa Pandemi Covid-19 Kepada Siswa-Siswi SMK Nurul Hikmah Langko Kabupaten Lombok Barat
}

\author{
Handry Sudiartha Athar ${ }^{*}$, Muhammad Sarjan', Lalu Hamdani Husnan² \\ ${ }^{1}$ Pascasarjana Universitas Mataram, Maratam, Indonesia \\ ${ }^{2}$ Fakultas Ekonomi Bisnis, Program Studi Manajemen, Universitas Mataram, Indonesia
}

DOI: $10.29303 /$ ujcs.v2i4.163

\section{Article Info}

Received: November 25, 2021

Revised: Desember 27, 2021

Accepted: Desember 31, 2021

\begin{abstract}
Abstrak: Dampak Covid-19 tidak hanya terjadi pada aspek kesehatan semata, tetapi merambah di dunia pendidikan. Kegiatan pengabdian ini bertujuan untuk melakukan pemberdayaan jiwa berwirausaha melalui kegiatan pelatihan kewirausahaan sebagai sarana menumbuhkan jiwa kewirausahaan agar siswa-siswi dapat mandiri setelah menamatkan pendidikannya. Metode pengabdian masyarakat ini dilakukan dengan cara ceramah bervariasi, demonstrasi, dan latihan. Hasil dari kegiatan ini dapat disimpulkan bahwa adanya peningkatan informasi dari siswa-siswi tentang kewirausahaan. Siswa siswi memiliki pemahaman yang lebih berkaitan dengan pentingnya memiliki jiwa kewirausahaan agar siswa-siswi dapat mandiri setelah menamatkan pendidikannya.

Kata Kunci: Pelatihan; Kewirausahaan; Covid-19.
\end{abstract}

Abstract: The impact of Covid-19 not only occurs on health aspects, but penetrates in the world of education. This devotional activity aims to empower the entrepreneurial spirit through entrepreneurship training activities as a means of fostering an entrepreneurial spirit so that students can be independent after completing their education. This method of community service is done by means of varied lectures, demonstrations, and exercises. The results of this activity can be concluded that there is an increase in information from students about entrepreneurship. Students have a more understanding related to the importance of having an entrepreneurial spirit so that students can be independent after completing their education.

Keywords: Training; Entrepreneurship; Covid-19.

Citation: Athar, H.S., Sarjan, M., \& Husnan, L.H. (2021). Pelatihan Kewirausahaan Pada Masa Pandemi Covid-19 Kepada Siswa-Siswi SMK Nurul Hikmah Langko Kabupaten Lombok Barat. Unram Journal of Community Service, 2(4), 122126. https://doi.org/10.29303/ujcs.v2i4.163

\section{Pendahuluan}

Dunia dilanda pandemi Covid-19 pada bulan Desember 2019 (Syafrida \& Hartati, 2020). Covid-19 saat ini menjadi virus yang paling ditakuti, karena sangat mematikan. Penyebarannya juga sangat cepat, dimulai dari Kota Wuhan China, sekarang menyebar ke seluruh Dunia (Pajarianto et al., 2020). Dampaknya tidak hanya terjadi pada aspek kesehatan semata, tetapi merambah di dunia pendidikan, dimana menyebabkan siswa merasa stres dengan proses pembelajaran daring, serta menimbulkan dampak kematian (Pajarianto et al., 2020; Jannah, 2021).

\footnotetext{
*Email: andre_sudiartha@yahoo.com

Indonesia merupakan salah satu Negara terkena Dampak pandemi Covid-19 (Pajarianto et al., 2020). Kegiatan perekonomian di seluruh provinsi mengalami perubahan yang cukup signifikan. Terdapat empat sektor yang paling tertekan akibat wabah virus corona atau Covid-19 yaitu rumah tangga, UMKM, korporasi, dan sektor keuangan (Bahtiar \& Saragih, 2020; Komara et al., 2020). Pertumbuhan ekonomi pun diprediksi akan mengalami kontraksi.

Pembatasan Sosial Berskala Besar (PSBB) yang berlaku mengharuskan aktivitas warga dilakukan dari rumah. Pendidikan terpaksa harus dilakukan secara daring. Hal ini tentunya membuat 
tingkat daya beli masyarakat menurun drastis karena mayoritas kegiatan pemenuhan kebutuhan hidup dilakukan secara konvensional terutama bagi keluarga miskin dan rentan yang bekerja di sektor informal. Akan tetapi, jika pada saatnya PSBB dilonggarkan oleh pemerintah hal ini dapat dilihat sebagai suatu peluang bagi masyarakat khususnya anak muda untuk berwirausaha.

Alangkah dewasanya apabila sebuah bangsa dan masyarakatnya mampu melihat masalah ini semua dengan bijak, bisa menjawab tantangan, serta tangguh menghadapi semua ancaman. Salah satu cara yang dirasa cukup ampuh adalah menumbuhkan dan menguatkan jiwa wirausaha (entrepreneurship) terutama dikalangan milineal. Diharapkan dengan menguatnya pemikiran serta tindakan kewirausahaan yang semakin masif, masyarakat dapat hidup mandiri dan bertahan sekalipun ditengah situasi sulit seperti saat ini. Entrepreneurship memiliki dampak positif bagi suatu perekonomian dan masyarakat, salah satu dampak terpenting dari entrepreneurship adalah penyediaan lapangan pekerjaan (Silvia, 2015).

SMK Nurul Hikmah Langko melaksanakan kegiatan belajar-mengajar sesuai dengan kurikulum yang telah ditentukan oleh Dinas Pendidikan. Pembelajaran yang menumbuhkan kewirausahaan belum semampunya ada terlebih membentuk suatu wadah seperti entrepreneur union untuk menanamkan jiwa berwirausaha setelah mereka menamatkan pendidikannya. Hal ini sangat dipandang perlu apabila diantara mereka belum memiliki perencanaan meningkatkan pendidikannya ke perguruan tinggi. Oleh sebab itu melalui pemberdayaan jiwa berwirausaha melalui kegiatan pelatihan kewirausahaan sebagai sarana menumbuhkan jiwa kewirausahaan agar siswasiswi dapat mandiri setelah menamatkan pendidikannya.

Tujuan dilaksanakan kegiatan Pengabdian Kepada Masyarakat ini adalah untuk melakukan pemberdayaan jiwa berwirausaha melalui kegiatan pelatihan kewirausahaan sebagai sarana menumbuhkan jiwa kewirausahaan agar siswasiswi dapat mandiri setelah menamatkan pendidikannya.

\section{Metode}

Metode pengabdian masyarakat ini akan dilakukan dengan cara :

1. Ceramah bervariasi.

Metode ini dipilih untuk menyampaikan konsep-konsep yang penting untuk dimengerti dan dikuasai oleh peserta pelatihan. Penggunaan metode ini dengan pertimbangan bahwa metode ceramah yang dikombinasikan dengan gambar-gambar, animasi dan display dapat memberikan materi yang relative banyak secara padat, cepat dan mudah. Peserta diberi motivasi agar memiliki spirit dan jiwa kewirausahaan yang tinggi dan melekat dengan cara mengubah paradigma berfikir peserta terkait dengan kegiatanberwirausaha.

\section{Demonstrasi}

Metode ini dipilih untuk menunjukkan suatu proses kerja yaitu Peserta diberikan kasus pemecahan dan konsep pengeloalan usaha dengan tujuan untuk meningkatkan pengetahuan kewirausahaan mereka.

\section{Latihan}

Metode ini digunakan untuk memberikan tugas kepada peserta, dalam hal Peserta pelatihan diberikan kesempatan untuk merancang usaha baru dengan membuat business plan yang visible, dan kemudian mempresentasikannya di depan forum untuk mendapatkan masukan dari kelompok yang lain.

\section{Hasil dan Pembahasan}

Berdasarkan kegiatan yang berlangsung Pelatihan Kewirausahaan Pada Masa Pandemi Covid19 Kepada Siswa-Siswi SMK Nurul Hikmah Langko Kabupaten Lombok Barat, berikut laporan pelaksanaan kegiatan

\section{Persiapan Konsep Kegiatan}

Persiapan awal terbentuknya kegiatan program Pelatihan Kewirausahaan Pada Masa Pandemi Covid19 Kepada Siswa-Siswi SMK Nurul Hikmah Langko Kabupaten Lombok Barat, terlebih dahulu ditetapkan lokasi kegiatan yang akan menjadi Mitra Universitas Mataram dalam melakukan kegiatan Pengabdian Kepada Masyarakat. SMK Nurul Hikmah Langko Kabupaten Lombok Barat merupakan salah satu yang dianggap sesuai dengan tema kegiatan yaitu pelatihan kewirausahaan, karena SMK Nurul Hikmah Langko berada di pedesaan dan cukup jauh dari perkotaan. Hal ini yang menjadikan Tim memilih lokasi tersebut karena akan sangat bermanfaat bagi siswa-siswi SMK Nurul Hikmah Langko untuk mengetahui tentang kewirausahaan tersebut. Setelah lokasi kegiatan ditentukan, kemudian dilakukan penetapan ketua dan anggota pengabdian dan dilanjutkan dengan pembentukan konsep kegiatan dimulai dari bulan April hingga Juli 2021.

Tahapan kedua adalah melakukan analisis kebutuhan yaitu dengan cara mengkaji hal-hal apa yang dibutuhkan dalam melakukan kegiatan pelatihan 
kewirausahaan di SMK Nurul Hikmah Langko. Tim kegiatan pengabdian melakukan analisis berdasarkan data-data yang telah diperoleh dan menetapkan kebutuhan prioritas yang harus disiapkan dalam memberikan pelatihan kewirausahaan.

Berdasarkan hasil diskusi ketua tim pengabdian dan pimpinan di SMK Nurul Himkah Langko maka disepakati bahwa pelatihan kewirausahaan memang sangat dibutuhkan oleh siswa siswi di sekolah tersebut. Proses ini berlangsung selama bulan Juni 2021. Penyusunan program pelatihan kewirausahaan dilakukan selama bulan Juli 2015.

\section{Persiapan Kegiatan}

Persiapan kegiatan dilakukan dengan diadakannnya rapat dengan tim. Rapat ini ditujukan untuk membahas persiapan kegiatan yang akan dilakukan pada bulan Agustus 2021. Selain rapat, persiapan kegiatan ini juga dilakukan dengan menghubungi pimpinan SMK Nurul Hikmah Langko untuk mempersiapkan tempat dan peserta kegiatan.

\section{Pelaksanaan Kegiatan}

Kegiatan Pelatihan Kewirausahaan Pada Masa Pandemi Covid-19 Kepada Siswa-Siswi SMK Nurul Hikmah Langko Kabupaten Lombok Barat. Kegiatan tersebut dilaksanakan dengan rincian sebagai berikut:

1) Acara Pembukaan

Kegiatan workshop dilaksanakan di SMK Nurul Hikmah Desa Langko Kabupaten Lombok Barat pada tanggal 26 Agustus 2021. Kegiatan diawali dengan pengabsenan peserta, kemudian peserta langsung diarahkan menuju ruangan kegiatan. Acara diawali dengan pembukaan yang kemudian dilanjutkan dengan sambutan oleh Ketua Yayasan Nurul Hikmah Langko.

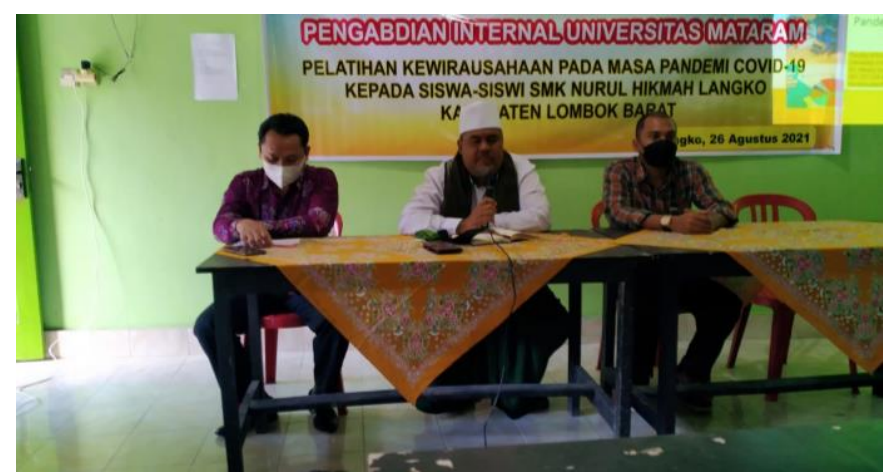

Gambar 1. Sambutan Ketua Yayasan Nurul Hikmah Langko

\section{2) Penyampaian Materi oleh Ketua Tim Pengabdian}

Penyuluhan ini disampaikan oleh Bapak Dr. Handry Sudiartha Athar, M.M. yang sekaligus sebagai ketua Tim Kegiatan Pengabdian. Beliau menyampaikan bagaimana cara menjadi enterpreneur yang handal dan memiliki usaha yang mudah diterima di Masyarakat. Saat itu juga beliau memberikan contoh produk yang mana yang layak dijual dan yang mana yang harus diperbaiki cara pengemasan makananya.

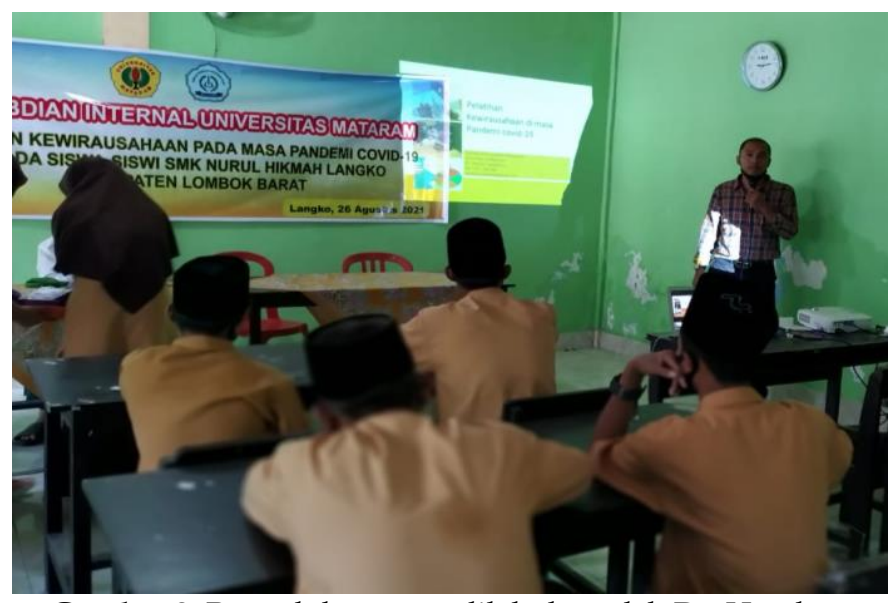

Gambar 2. Penyuluhan yang dilakukan oleh Dr. Handry Sudiartha Athar

\section{3) Sesi Diskusi}

Pada tahapan ini, siswa siswi diberikan kesempatan untuk bertanya terkait dengan materi yang sudah disampaikan. Menariknya adalah ada 3 pertanyaan kemudian didiskusikan bersama. Pertama, pertanyaan yang disampaikan oleh siswa an. Jumadil. Pertanyaannya adalah bagaimana cara cepat mempromosikan barang dagangan supaya cepat laku dan cepat menghasilkan uang? Pertanyaan ini kemudian langsung dijawab oleh Dr. Handry bahwa Kunci sukses seorang pebisnis ternyata tak hanya terletak pada kualitas barang yang dipasarkan, tapi juga dilihat dari cara promosi yang dijalankan. Bahkan sebagus apapun produkmu, tak kan dikenali orang tanpa didukung strategi promosi yang efektif. Tidaklah heran jika banyak pebisnis yang rela menggelontorkan dana yang tak sedikit hanya untuk keperluan promosi. Tetapi untuk kamu yang masih pebisnis pemula, tak perlu sampai menghabiskan dana sampai berdarahdarah untuk memikat calon konsumen. Sebab, cara promosi produk, tidak selamanya membutuhkan biaya besar. Kamu yang memiliki dana terbatas sekalipun juga bisa menyusun strategi promosi untuk mendongkrak penjualan produk. Sebagai tambahan informasi, berikut kami informasikan 18 cara promosi cerdas, bahkan nyaris tanpa biaya sedikitpun yang bisa kamu jalankan agar barang daganganmu laku keras di pasaran.

Pertanyaan kedua muncul dari salah satu siswa an. Hilyatul Jannah. Pertanyaannya adalah sebagai pemula kami tentu bingung dengan apa yang harus dikerjakan dalam membuat usaha, langkah apa saja yang harus dilakukan? Pertanyaan tersebut juga 
langsung dijawab oleh Dr. Handy. Jawabannya adalah Saat ini, banyak orang-orang yang semakin sulit untuk mendapat pekerjaan, apalagi bagi orang-orang yang tidak memiliki keahlian khusus. Membuka usaha sendiri dapat menjadi suatu peluang bagi Anda untuk menghasilkan uang. Apabila Anda tertarik membuka usaha sendiri, langkah-langkah yang harus dilakukan adalah:

\section{- Menganalisis jenis usaha terkait}

Anda harus memastikan bahwa usaha yang Anda dirikan adalah jenis usaha yang Anda minati. Setelah itu susun rencana pemasaran yang akan Anda lakukan untuk memasarkan usaha Anda tersebut.

\section{Rencanakan Bisnis Anda dengan menyusun konsep yang sesuai}

Jika Anda akan membiayai usaha itu sendiri, rencana usaha juga akan membantu Anda mengetahui berapa banyak uang yang Anda akan butuhkan untuk memulai, apa yang perlu untuk dilakukan kapan, dan di mana Anda tuju.

\section{- Siapkan Modal}

Modal merupakan faktor penting dalam memulai usaha sendiri. Banyak orang ingin memulai usaha, namun tak mempunyai modal sehingga tidak jalan. Modal dapat dihasilkan dari: modal sendiri dari hasil menabung, atau meminjan uang dari bank, dan sistem partnership. Anda juga dapat memulai bisnis tanpa modal dengan menjadi reseller (pengecer) dari suatu produk atau barang.

Intinya adalah, dalam memulai usaha apalagi sebagai pemula, maka lakukanlah usaha sesuai dengan minat. Jangan asal ikut-ikutan. Karena itu akan menentukan keberlangsungan usaha Anda.

Pertanyaan ketiga muncul dari siswi lagi an. Fidyatul Jannah. Pertanyaannya adalah Kami ini masih sekolah Pak, jika mau melakukan usaha bagaimana dengan modal. Kalau pinjam di Bank pasti kami tidak dipercaya. Pertanyaan tersebut langsung dijawab oleh Dr. Handry. Jawabannya adalah Modal memang memegang peranan penting untuk membuka usaha. Tanpa modal yang cukup maka kebutuhan-kebutuhan usaha akan terhambat. Maka dari itu, kita harus benar-benar bisa memenuhi modal awal perusahaan rintisan kita.

Memiliki usaha tak perlu terburu-buru untuk segera mendirikannya. Setelah kita memiliki ide, kita bisa memasang target kapan usaha kita akan mulai beroperasi sehingga kita bisa menabung untuk mendapatkan suntikan modal. Mendanai modal usaha dari dana pribadi merupakan cara paling aman. Karena jika terjadi kegagalan perusahaan tak ada sangkut pautnya dengan pihak luar. Meskipun usaha yang dibuka masih kecil dan bersifat lokal, kita harus tetap memperdulikan kebutuhan jangka panjang ketika akan mendirikan sebuah usaha.

\section{Kesimpulan}

Berdasarkan kegiatan pengabdian yang telah dilakukan maka disimpulkan bahwa siswa-Siswa SMK Nurul Hikmah Langko sangat antusias dengan kegiatan pelatihan kewirausahaan ini. Mereka sangat membutuhkan informasi-informasi berkaitan dengan usaha apa yang menarik untuk mereka lakukan yang sesuai dengan minat dan kemampuan mereka. Dengan demikian, hasil dari kegiatan ini dapat disimpulkan bahwa adanya peningkatan informasi dari siswa-siswi tentang kewirausahaan. Siswa siswi memiliki pemahaman yang lebih berkaitan dengan pentingnya memiliki jiwa kewirausahaan agar siswa-siswi dapat mandiri setelah menamatkan pendidikannya.

\section{Ucapan Terima Kasih}

Tim penulis mengucapkan terima kasih kepada semua pihak yang telah membantu terlaksananya kegiatan pengabdian kepada masyarakat ini. Penulis mengucapkan terima kasih kepada Ketua Yayasan Pondok Pesantren Nurul Hikmah Langko dan Kepala Sekolah SMK Nurul Hikmah Langko Kabupaten Lombok Barat persiapan terselenggaranya kegiatan ini.

\section{References}

Bahtiar, R. A., \& Saragih, J. P. (2020). Dampak Covid19 terhadap perlambatan ekonomi sektor umkm. Jurnal Bidang Ekonomi Dan Kebijakan Publik, 7(6), 19-24.

Jannah, R. (2021). Tingkat Stres Mahasiswa Mengikuti Pembelajaran Daring pada Masa Pandemi Covid19. Jurnal Riset Dan Pengabdian Masyarakat, 1(1), 130-146.

Komara, B. D., Setiawan, H. C. B., \& Kurniawan, A. (2020). Jalan Terjal UMKM dan Pedagang Kecil Bertahan di Tengah Pandemi Covid-19 dan Ancaman Krisis Ekonomi Global. Jurnal Manajemen Bisnis, 17(3), 342. https://doi.org/10.38043/jmb.v17i3.2506

Pajarianto, H., Ukkas, I., \& Pribadi, I. (2020). Pengembangan Kewirausahaan Di Universitas Muhammadiyah Palopo. SELAPARANG Jurnal Pengabdian Masyarakat Berkemajuan, 4(1), 442. https://doi.org/10.31764/jpmb.v4i1.3230

Silvia. (2015). Pengaruh Entrepreneurial Traits Dan Entrepreneurial Skills Terhadap Intensi Kewirausahaan. Agora, 3(1), 358-363. 
Syafrida, S., \& Hartati, R. (2020). Bersama Melawan Virus Covid 19 di Indonesia. SALAM: Jurnal Sosial

Dan Budaya Syar-I, 7(6), 495-508.

https://doi.org/10.15408/sjsbs.v7i6.15325 